\title{
EU structural and cohesion policy and sustainable development
}

Originally published as:

Bettina Bahn-Walkowiak, Arkaitz Usubiaga, Philipp Schepelmann (2012):

EU structural and cohesion policy and sustainable development

In: Larry Kreiser ... (ed.): Carbon pricing, growth and the environment. - Cheltenham :

Elgar, 2012, pp. 17-32 
Bettina Bahn-Walkowiak ${ }^{\text {a }}$, Arkaitz Usubiaga a , Philipp Schepelmann ${ }^{\mathrm{a}}$

\section{EU structural and cohesion policy and sustainable development}

a Wuppertal Institute for Climate, Environment and Energy, Wuppertal, Germany

* Corresponding author: Bettina Bahn-Walkowiak, Wuppertal Institute for Climate, Environment and Energy, Döppersberg 19, 42103 Wuppertal, Germany

E-mail: bettina.bahn-walkowiak@wupperinst.org

Phone: +49 202 2492-276

Fax: +49202 2492-250 


\section{Introduction}

This chapter is an excerpt from a study commissioned by the European Parliament, which examines EU subsidies for agriculture, fisheries, transport, energy and regional development. Based on proven methodologies for the identification and assessment of environmentally harmful subsidies, the study assesses the sustainability level of the sectoral policies and makes recommendations for a reform that would contribute to the alignment of the EU budget towards a more sustainable growth. The following sections provide the main findings of one of the largest fields of expenditure within the EU budget, the structural and cohesion policy.

\section{The Struture and Priorities of the EU Structural and Cohesion Funds}

The European Structural and Cohesion Funds aim to reduce social and economic disparities between the European regions. Due to several tens of thousands of projects being supported within one programming period, it is difficult to find coherent evidence on the output and results of the EU regional policy. Aggregated information is rare, whereas diverging and country-specific indicator-based data of partly insufficient quality are prevalent.

In the programming period 2000-2006, the regional policy instruments mainly focused on the European regions lagging behind (objective 1) and the regions that were undergoing structural change (objective 2) at that time (Nordregio, 2009). For the following programming period, 2007-2013, a reform of the regional policy was implemented by introducing the term territorial cohesion. The overarching target of the financial support is to reduce imbalances and disparities between the manifold European regions under the umbrella of convergence, competitiveness and cooperation (EC, 2004, 2010a, 2010b). At the same time, Article 17 'Sustainable development' of the Council Regulation No 1083/2006 declares that the 'objectives of the funds shall be pursued in the framework of sustainable development and the Community promotion of the goal of protecting and improving the environment ... ' (EC, 2006a).

In the running period 2007-2013, the European cohesion policy will benefit from 36 per cent of the total EU budget (approx $€ 344$ billion) (EC, 2010c). The European Regional Development Fund (ERDF) will assign $€ 200$ billion to regional development, economic change, enhanced competitiveness and territorial cooperation, the European Social Fund (ESF) $€ 75$ billion to employment, social inclusion and tackling discrimination; and the Cohesion Fund $€ 70$ billion to environment and transport.

The programming period 2007-2013 covers the following priorities:

1. Convergence (81.5 per cent): promotion of growth-enhancing conditions and factors leading to convergence of the least-developed Member States and regions,

2. Regional competitiveness and employment (16 per cent): promotion of economic change through innovation and the support of the knowledge society, entrepreneurship and the protection of the environment,

3. Territorial cooperation ( 2.5 per cent): cross-border and transnational cooperation, joint local and regional initiatives, interregional cooperation and exchange of experience (EC, 2007a: Nordregio, 2009).

In the Council Decision 'Community Strategic Guidelines (CSG) on economic, social and territorial cohesion, 2007-2013' it is constituted that the 'cohesion policy should focus to a greater extent on knowledge, research and innovation, and human capital' (EC, 2006b), 
while increasing resources accordingly. A second priority is the objective of sustainable development by emphasising the role of the environment in growth, competitiveness and employment. Synergies between environmental protection and growth are assumed to be strengthened by decreasing the external environmental costs and stimulating innovation and job creation. The requirement 'to reduce traditional energy dependency through improvements in energy efficiency and renewable energies' is also stressed (EC, 2006b).

The programming system follows different stages: The National Strategic Reference Frameworks (NSRF) 2007-2013 contain the overall development strategies of the Member States and constitute the scope for the thematic and regional programmes. The Operational Programmes (OPs) specify the activities and priorities at Member State level. Strategic Environmental Assessments (SEA) and Environmental Impact Assessments (EIA) have to be applied where required (GRDP, 2006). SEAs of complete planning processes and EIAs of individual projects are, however, both often assessed as being insufficient (BirdLife, 2010).

\subsection{The Evaluation Process}

The evaluation process of the structural and cohesion policy carries out strategic ex-ante evaluations with an EU-wide dimension, thematic ex-ante evaluations of planned programmes, intermediate evaluations of running programmes and ex-post evaluations of completed programmes. The programming and evaluation process are interdependent. The ex-ante evaluations for the programming period 2007-2013 were conducted at varying stages in the process of writing the OPs. The objective of the ex-ante process is to improve the focus of the programmes and to increase transparency and efficiency. Besides, a consistency check is to be made in order to ensure a correspondence between Community priorities and the regions' requirements (Nordregio, 2009).

For the current period, a shift from the concept of mid-term evaluations (compulsory evaluations at predetermined points of the programming period) towards a more flexible, demand-driven approach to evaluation (ongoing evaluation in the Member State responsibility) has been implemented (EC, 2007c; Applica/lsmeri, 2010a). The ongoing evaluation is being done in the form of a series of evaluation exercises that check the physical and financial performance of the OPs.

Apart from a great complexity of the whole management and control structure, it is not always clear if the impacts in some Member States are in fact attributable to the policy, since the effectiveness of the monitoring and evaluation is sometimes carried out with poor data.

\section{Results of the Mid-term Evaluation of the European Regional Development Fund} 2007-2013

The added value gained by the cohesion policy and its current design is undoubtedly the leverage effect of the resources for less developed European regions. The multi-annual planning allows for consolidated support and potential refocusing of objectives from a midterm perspective. The earmarking of public resources and the monitoring and evaluation process increase the political credibility and accountability. The territorial dimension supports interregional cooperation and the sharing of best practices. However, interest groups, NGOs and research institutions are also critical from different perspectives. 


\subsection{Selection of Resources and the Implementation Process}

Interestingly, the implementation of the programmes is delayed in almost all Member States. The years 2008/2009 have shown that Member States 'failed to take advantage of a significant part of the financial support available to them from the Structural Funds' (Applica/Ismeri, 2010b, p. 59; Applica/Ismeri, 2010a; FoEE, 2010). Figures of €93.4 billion (27 per cent) of the total available EU cohesion policy resources and $€ 63$ billion of the earmarked projects had been selected at the midway point (EC, 2010b). Contrariwise, it has to be considered if and to what extent the Structural and Cohesion Funds 'played an important role in helping to counter the effects of the economic downturn' which however, 'raises a questionmark over additionality' (Applica/Ismeri, 2010b, p. 59).

Due to the complexity of the funding mechanisms, European projects 'are driven more and more by compliance with administrative procedures rather than development strategy' (CoR, 2010). The fragmentation of the EU funding can also hamper effective implementation. Moreover, the evaluation of the degree of fund implementation redirects the focus away from the actual performance and effectiveness of the projects supported. The Committee of the Regions (CoR, 2010) suggests a reporting methodology focusing on the results rather than on the financial performance.

\subsection{Relationship between Earmarking of Funds and Sustainable Development}

A considerable part is earmarked for growth targets. The EU15 Member States are committed and the EU12 Member States are asked to select their programmes on a voluntary basis accordingly, that is 60 per cent Lisbon earmarking in respect of the Convergence programmes and 75 per cent in respect of the Regional and Competitiveness and Employment programmes. Thus, $€ 230$ billion are targeted on Lisbon priorities. During the programming period, Member States have to report on the progress by submitting a 'National Strategic Report' showing how the cohesion policy is contributing to the Lisbon Strategy (EC, 2007b). This inevitably makes sustainable development targets take a back seat. A study which compares the cohesion policy expenditure with the policy priorities expressed in the OPs, and thus investigates the potential for regional policy instruments to contribute to the Lisbon (for growth and jobs) and Gothenburg objectives (for sustainable development), claims that - not surprisingly - the OPs related to the Convergence principle (e.g. infrastructural themes such as ICT accessibility and transport; innovation support and economic growth) are the most important (Nordregio, 2009). Within the Gothenburg context and sustainable development objectives, the management of natural resources, clean water, air and soil and sustainable transport are the most important priority themes.

The study shows that countries that commit less to Lisbon objectives tend to focus on environmental protection and risk prevention categories (e.g. Bulgaria, Romania, Estonia, Malta, Lithuania, Hungary and Cyprus at around 20-30 per cent) (Well, 2009). A third of the programmes have an integrated three-pillar approach to sustainable development, but a 'de facto emphasis on [the] economic dimension' (especially in Convergence OPs) (Nordregio, 2009, p. 93). According to the study, the Lisbon Strategy is more short-term oriented, whereas Gothenburg goals include longer-term commitments (Nordregio, 2009). It recommends reconciling this imbalance in the cohesion policy and positioning the concept of sustainable development as the overarching principle to EU regional funding. 


\section{Identification of Potientially Environmentally Harmful Subsidies within the}

European Regional Development Fund 2007-2013

The OECD 'quick scan' tool $(1998,2005)$ asserts that the impacts of a subsidy on the environment depend on the conditions of the support and on the size of the subsidy that determines the distortionary impacts on the marginal costs or revenues of the recipient sector (Valsecchi et al., 2009). The identification of the key items of the EU structural and cohesion policies in the current EU budget that do not fulfil the set sustainability criteria is confronted with a lack of data in the mid-term (or ongoing) evaluation reports (CoR, 2010). The monitoring reports provide data on the number of projects, the policy implementation rate, the allocation of financial means, the allocation between the objectives, 'convergence, competitiveness and cooperation', etc. They do not refer to sustainable development indicators (Eurostat 2009).

Single indicator systems of certain programmes can be of good quality 'but as soon as we try to establish a comprehensive picture across programmes, we face severe problems due to the inconsistency of indicators and the varying quality of data' (Schwab, 2010, p. 3). There is no commonly agreed process of relating ERDF environmental indicators to the European Sustainable Development Strategy. For this reason, the following section will refer to comprehensive approaches such as the Transport and Environment Reporting Mechanism (TERM) of the European Environment Agency, which compiles macro-data for the transport sector of all European countries and draws conclusions at a macro-level.

\subsection{Proportions within the Environmental Funding Framework}

The total Structural and Cohesion Funds comprise approx $€ 344$ billion. The environment spending is at a record for this period as it is three times higher than in the previous period 2000-2006 (EC, 2009). The budget comes up to about 30 per cent of the total fund, that is around $€ 105$ billion. Although such a high budget is contributing to a wide range of positive environmental impacts, the proportions of the environmental funding for different themes in the programming period 2007-2013 have to be examined more closely.

There are 86 priority themes or investment categories within the programming period 20072013. The CSG theme Environment covers 12 priority themes, but further environmentrelated themes can be found in other CSG themes (EC, 2010b). Altogether, 21 categories have an ecological focus. Table 2.1 shows the allocation of planned subsidies with respect to CSG themes.

Table 4-1: Allocation of resources within the environmental framework of Structural and Cohesion Funds and share of funding in percentage, 2007-2013

\begin{tabular}{rlrrr}
\hline No & Category & $\begin{array}{c}\text { Planned EU } \\
\text { environmentally- } \\
\text { friendly investments } \\
\text { (million } € \text { ) }\end{array}$ & $\begin{array}{c}\text { Percentage of } \\
\text { environmental } \\
\text { funding }\end{array}$ & $\begin{array}{c}\text { Percentage } \\
\text { of total } \\
\text { funding }\end{array}$ \\
\hline 6 & Eco-innovation SMEs & 2476 & $2.4 \%$ & $0.7 \%$ \\
16 & Railways & 4133 & $4.0 \%$ & $1.2 \%$ \\
17 & Railways (TEN-T) & 18428 & $17.7 \%$ & $5.4 \%$ \\
18 & Mobile rail assets & 629 & $0.6 \%$ & $0.2 \%$ \\
19 & Mobile rail assets (TEN-T) & 666 & $0.6 \%$ & $0.2 \%$ \\
24 & Cycle tracks & 604 & $0.6 \%$ & $0.2 \%$ \\
25 & Urban transport & 1660 & $1.6 \%$ & $0.5 \%$ \\
26 & Multimodal transport & 1629 & $1.6 \%$ & $0.5 \%$ \\
27 & Multimodal transport (TEN-T) & 447 & $0.4 \%$ & $0.1 \%$ \\
\hline
\end{tabular}




\begin{tabular}{|c|c|c|c|c|}
\hline No & Category & $\begin{array}{c}\text { Planned EU } \\
\text { environmentally- } \\
\text { friendly investments } \\
\text { (million } €)\end{array}$ & $\begin{array}{l}\text { Percentage of } \\
\text { environmental } \\
\text { funding }\end{array}$ & $\begin{array}{c}\text { Percentage } \\
\text { of total } \\
\text { funding }\end{array}$ \\
\hline 28 & Intelligent transport systems & 1086 & $1.0 \%$ & $0.3 \%$ \\
\hline 29 & Inland waterways (regional and local) & 268 & $0.3 \%$ & $0.1 \%$ \\
\hline 30 & Inland waterways (TEN-T) & 604 & $0.6 \%$ & $0.2 \%$ \\
\hline 39 & Renewable energy: wind & 785 & $0.8 \%$ & $0.2 \%$ \\
\hline 40 & Renewable energy: solar & 1064 & $1.0 \%$ & $0.3 \%$ \\
\hline 41 & Renewable energy: biomass & 1786 & $1.7 \%$ & $0.5 \%$ \\
\hline 42 & $\begin{array}{l}\text { Renewable energy: hydroelectric, } \\
\text { geothermal and other }\end{array}$ & 1124 & $1.1 \%$ & $0.3 \%$ \\
\hline 43 & $\begin{array}{l}\text { Energy efficiency, cogeneration, } \\
\text { energy management }\end{array}$ & 4270 & $4.1 \%$ & $1.2 \%$ \\
\hline 44 & $\begin{array}{l}\text { Management of household and } \\
\text { industrial waste }\end{array}$ & 6239 & $6.0 \%$ & $1.8 \%$ \\
\hline 45 & $\begin{array}{l}\text { Management and distribution of water } \\
\text { (drink water) }\end{array}$ & 8144 & $7.8 \%$ & $2.4 \%$ \\
\hline 46 & Water treatment (waste water) & 13887 & $13.3 \%$ & $4.0 \%$ \\
\hline 47 & Air quality & 1018 & $1.0 \%$ & $0.3 \%$ \\
\hline 48 & $\begin{array}{l}\text { Integrated prevention and pollution } \\
\text { control }\end{array}$ & 739 & $0.7 \%$ & $0.2 \%$ \\
\hline 49 & $\begin{array}{l}\text { Mitigation and adaptation to climate } \\
\text { change }\end{array}$ & 305 & $0.3 \%$ & $0.1 \%$ \\
\hline 50 & $\begin{array}{l}\text { Rehabilitation of industrial sites and } \\
\text { contaminated land }\end{array}$ & 3451 & $3.3 \%$ & $1.0 \%$ \\
\hline 51 & $\begin{array}{l}\text { Promotion of biodiversity and nature } \\
\text { protection (Natura 2000) }\end{array}$ & 2676 & $2.6 \%$ & $0.8 \%$ \\
\hline 52 & Promotion of clean urban transport & 6127 & $5.9 \%$ & $1.8 \%$ \\
\hline 53 & Risk prevention & 5801 & $5.6 \%$ & $1.7 \%$ \\
\hline 54 & $\begin{array}{l}\text { Other measures to preserve the } \\
\text { environment and prevent risks }\end{array}$ & 1676 & $1.6 \%$ & $0.5 \%$ \\
\hline 55 & Promotion of natural assets & 1137 & $1.1 \%$ & $0.3 \%$ \\
\hline 56 & $\begin{array}{l}\text { Protection and development of natural } \\
\text { heritage }\end{array}$ & 1405 & $1.3 \%$ & $0.4 \%$ \\
\hline 61 & $\begin{array}{l}\text { Integrated projects for urban and rural } \\
\text { regeneration }\end{array}$ & 10136 & $9.7 \%$ & $2.9 \%$ \\
\hline \multicolumn{2}{|c|}{ Total environment funding } & 104400 & $100 \%$ & $30.3 \%$ \\
\hline \multicolumn{2}{|c|}{ Total budget } & 344306 & & \\
\hline & CSG theme: RTDI & & & \\
\hline & CSG theme: Transport & & & \\
\hline & CSG theme: Energy & & & \\
\hline & CSG theme: Environment & & & \\
\hline & CSG theme: Territorial dimension & & & \\
\hline
\end{tabular}

Source: Authors' own compilation with data from EC (2010b).

In general, the CSG theme Environment is more oriented towards end-of-pipe approaches such as management of household and industrial waste, rehabilitation of industrial sites and contaminated land (approx 69 per cent of the financial volume) than towards prevention approaches such as integrated prevention and pollution control or risk prevention (approximately 31 per cent of the financial volume of projects).

When the environmental framework is structured alongside the categories infrastructure, climate change, renewable energy and biodiversity, a very dominant proportion of subsidies for infrastructural projects becomes apparent in the total Funds 2007-2013. 


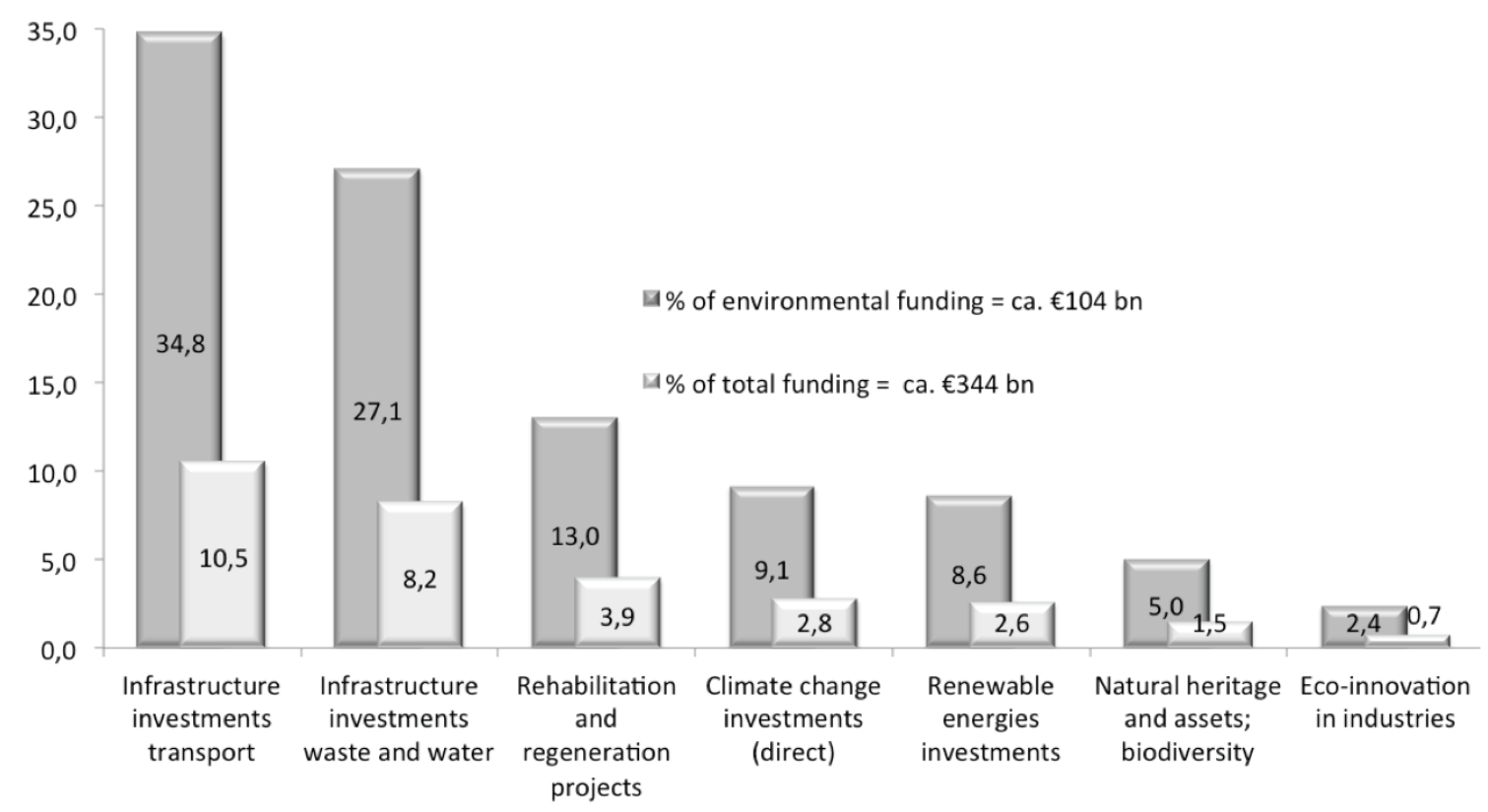

Source: Authors' own compilation with data of EC (2010b).

Figure 4-1 : Proportions of environmental funding for different themes, 20072013

More than 62 per cent of the budget is selected for infrastructure investment projects in the field of transport (i.e. environmentally-friendly transport modes such as railways), waste and waste water. A further 13 per cent refers to rehabilitation and regeneration projects. It is striking that direct climate change investments only amount to 9.1 per cent (2.6 per cent of the total Structural and Cohesion Funds budget). Subsidies for renewable energies represent only 8.6 per cent of the environmental budget ( 1.5 per cent of the total budget), support for eco-innovation 2.4 per cent ( 0.7 per cent of total funding) and projects within the field of natural heritage and biodiversity 5 per cent ( 1.5 per cent of total).

\subsection{Road-based Transport Infrastructure Investments}

When the budget is scrutinised in detail, it is striking that a large proportion of the total budget is dedicated to transport infrastructure investments (24 per cent). These investments comprise both sustainable and unsustainable transport modes. In this context, a breakdown shows that 49 per cent of the investments are selected for motorways and roads (within and without the Trans-European Networks - Transport (TEN-T) and national and regional roads). Twenty-nine per cent are planned for railways (within and without TEN-T and mobile assets), while only 2 per cent are planned for urban transport and 7 per cent for the promotion of clean urban transport.

In fact, a considerable amount of the cohesion policy funding (almost 12 per cent) is used to subsidise transport infrastructure projects that contribute to an increased use of nonrenewable resources, irreversible landscape alterations and greenhouse gas emissions (EC, 2010b; BirdLife, 2010). There is a striking imbalance in favour of one of the least efficient and least sustainable transport modes, that is, roads and motorways, entailing private mobility and heavy goods traffic.

As for the ten central and eastern European Member States (CEE10), the imbalance is even greater due to high development gaps in the transport sector. Approximately half of the amount of the Structural and Cohesion Funds will go to CEE10 countries. It is planned that approximately 30 per cent of the total for these countries, that is, almost $€ 50$ billion, will be 
invested in transport. Fifty-three per cent of the total funds will be allocated to road infrastructures, 30 per cent to rail infrastructures, and the remaining 17 per cent to mixed or urban transport modes (CEE Bankwatch Network, 2007).

A further difficulty is that Member States are not required to guarantee that the support of the transport sector would not cause an increase in greenhouse gas emissions (BirdLife, 2010).

The latest trends confirm that road-dominated investments contribute to an unsustainable path in transport development (EEA, 2010). The report comes to the conclusion that 'passenger and freight transport by road will remain the principal mode of travel with the greatest market share if present trends continue and no action is taken to reduce emissions' (EEA, 2010, p. 22).

If the EU wants to promote sustainable transport and tackle climate change, its transport funding should be systematically re-focused on urban and regional public transport, sustainable traffic management, cycling, rail transport, and intermodal infrastructure, shifting freight from road to rail.

\subsection{Direct and Indirect Climate Change Mitigation}

The topic of climate change mitigation has to be considered in connection with the previous section. Greenhouse gas emissions from transport continue to rise steadily and now account for 19.3 per cent of EEA member country emissions (EEA, 2010). The expenditure for the category Mitigation and adaptation of climate change within the financial framework in the EU is rather small, with 9.1 per cent of the funding for environmental projects (2.8 per cent of total funding, see Figure 2.1; see also BirdLife, 2010).

Following the 'European Commission Strategy Report', the following categories are correctly classified as measures with direct relieving effects (see Figure 2.2): energy efficiency measures (4.1 per cent), support of renewable energies (4.5 per cent), measures to improve the air quality (1.0 per cent), risk prevention (5.5 per cent) (EC, 2010b). It is controversial, however, to what extent investments for the expansion of infrastructures contribute to environmental relief (ADE, 2008). After using large amounts of resources and energy for the investment itself, its sustainability will be determined by the mid- to long-term reduction in greenhouse gas emissions. This is associated with a necessary shift from freight and passenger transport to rail transport, which will have to grow in order to show environmental relief. 


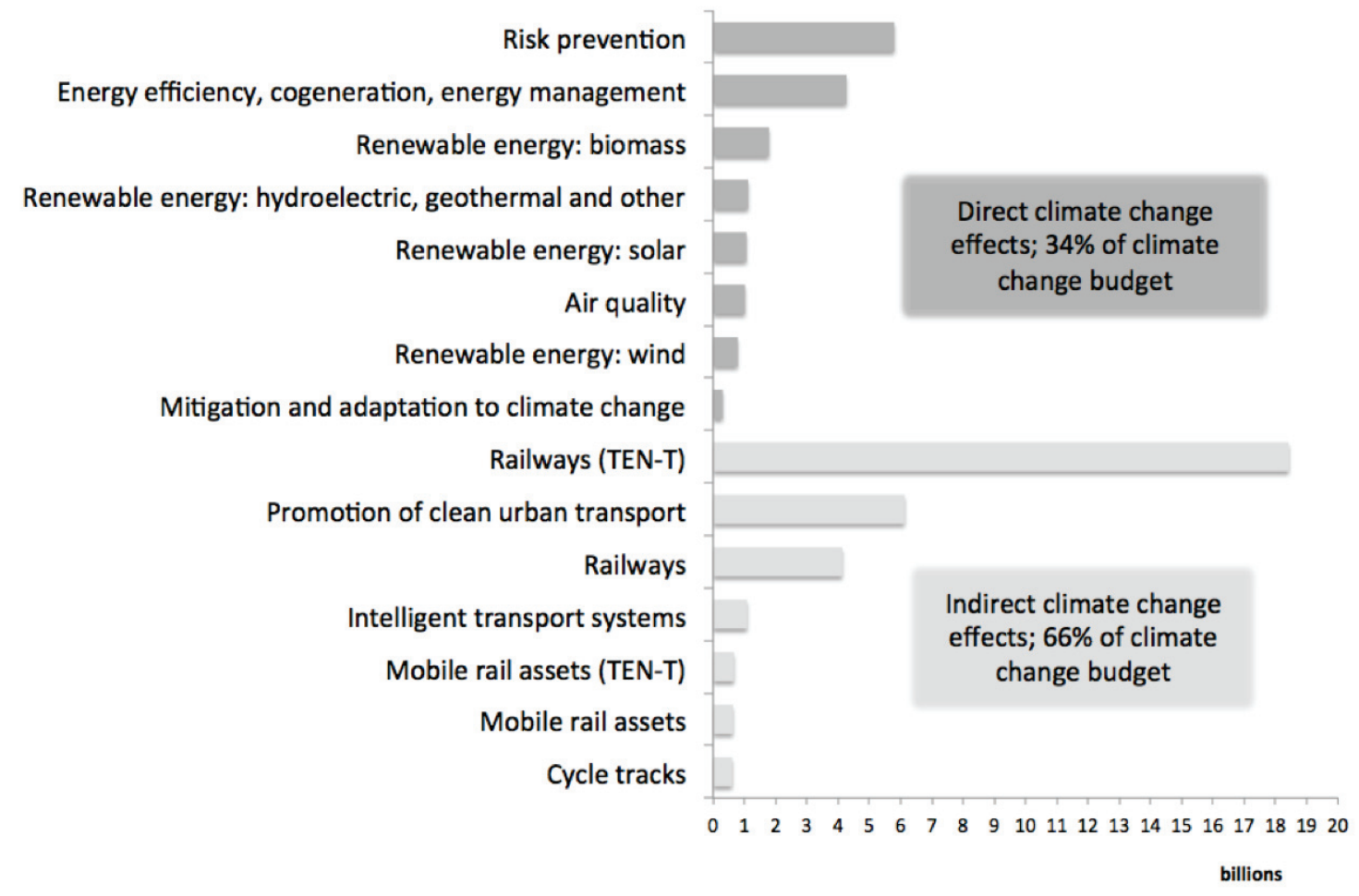

Source: Authors' own compilation.

\section{Figure 4-2: Allocation of climate change investments according to category themes, 2007-2013}

In the context of climate change mitigating measures, buildings are estimated to account for up to 40 per cent of energy use, with the resulting carbon emissions being substantially more than those in the transport sector. Considering that large parts of the greenhouse gas emissions result from, inter alia, poor thermal insulation and waste of energy in residential and commercial buildings, subsidies for energy efficiency measures appear much lower (4.1 per cent) compared to the other categories (Stefanova and Konecny, 2008).

\subsection{Further Aspects: Waste Incineration and Biodiversity}

Infrastructure investments for waste and water (and waste water) are, at 27.1 per cent, the second largest part of the environmental section of the Structural and Cohesion Funds and amount to 8.2 per cent of the total fund (see Figure 2.1). Several studies report a large number of waste incineration projects (up to 100), particularly in the CEE10 countries, for example Lithuania, Czech Republic, Croatia, Hungary, Slovakia and Poland (CEE Bankwatch Network, 2009). These projects set the wrong market incentives and block valuable funding for more cost-effective and sustainable waste solutions such as separate collection, recycling and composting (FoEE, 2009; Simon, 2010), all of which might jeopardise the achievement of waste recycling targets set by the EU.

Regarding biodiversity, NGOs complain that EU funding and EU policies are conflicting and that more transparency is required in terms of sound information and monitoring of impacts (Mey, 2010). An obligatory participation of stakeholders in the monitoring committees of the ERDF is presently not implemented. Biodiversity and Natura 2000 comprise only a small part $(2.5 \%)$ and are not funding priorities (WWF, 2006). 


\section{Conclusions}

By focusing on competitiveness and growth, the new period of 2007-2013 led to a paradigm shift in regional policy prompting adjustments in the orientation of the Member States' programmes content away from the Gothenburg objectives. Moreover, although large parts of the EU structural funding are environment-related, it is still primarily focused on end-ofpipe environmental protection (Schepelmann et al., 2009).

\subsection{Earmarking for Environmental Priorities}

In order to maximise the leverage effect, the EU cohesion policy should concentrate on projects that deliver the largest environmental benefits at European level, and thus reflect European priorities. The earmarking of financial means should upgrade the sustainable development principle to a priority principle. The relationship between growth, infrastructure and environmental quality, and the dynamic interplay between them, has to be examined more systematically because investment costs are borne in the short term while benefits appear in the long run (ADE, 2008, p. 48).

Green Public Procurement could be incorporated as a condition for the granting of funds. That way EU funds could be systematically used to promote green products and services and gain additional environmental benefits. The green market segment can essentially be strengthened, thus sending further transformational messages to economic operators (BirdLife, 2010).

In this context, subsidies of the Structural and Cohesion Funds should be environmentally and cost effective in the long term, and the EU should therefore primarily support solutions that have proven to be environmentally and cost effective over time (ADE, 2008).

\subsection{Closing the Knowledge Gap: Review of the Evaluation Process}

As the costs are borne by the public (i.e. the taxpayers), transparency, good quality information and accessible data are most important for political credibility, in particular in the field of subsidies. The EU Structural and Cohesion Funds should provide full disclosure.

Existing sectoral environmental and sustainability assessments like TERM (EEA, 2010) or Energy and Environment Reports (EEA, 2006) currently fill the gap of the insufficient monitoring and ex-post evaluation process as regards the fulfilment of sustainability criteria. These assessments are an essential and recommended tool to deliver insights on environmental impacts, and to partly counterbalance methodological and data constraints that limit comparisons of sector-specific analyses.

In the future, the ex-ante, mid-term and ex-post evaluations could use compulsory indicators aligned with the 'Sustainable Development Indicators'. As the current indicators are mainly concentrated on management and financial control, it is advisable to introduce indicators for measuring the environmental impacts.

Throughout all evaluation and monitoring tools, there should be more systematic differentiation between environmental projects with direct and indirect positive impacts in the short, middle and long term. 


\subsection{Closing the Governance Gap: Increase of Policy Coherence}

In order to increase the coherence within and across European policies and instruments, the Structural and Cohesion Funds should be both part and the result of an integrated strategy (Schepelmann, 2010). The targeted spending of public money for a limited number of priorities that are clearly identified and justified is essential. The Lisbon priorities of growth and jobs are very broad and partly conflict with environmental objectives. The relationship between the two main principles growth and jobs and sustainable development needs clarification. As an important step in order to strengthen the coherence with the Europe 2020 strategy (EC, 2010d) and the Roadmap to a Resource Efficient Europe of 2011 (EC, 2011), 'resource efficiency' should be systematically integrated as a core criterion for the projects, supported by the regional policy of the EU, and related indicators for disclosing Member States' performance in this regard have to be established.

\section{References}

ADE (2008), Ex post evaluation of cohesion policy programmes 2000-2006 co-financed by the European Fund for Regional Development (Objectives 1 and 2) - Work package 5b: Environment and Climate Change - Revised First Intermediate Report, Louvain-la-Neuve.

Applica/lsmeri (2010a), Expert Evaluation Network delivering policy analysis on the performance of cohesion policy 2007-2013: Inception report, Brussels.

Applica/Ismeri (2010b), Evaluation Network delivering policy analysis on the performance of cohesion policy 2007-2013: Synthesis of national reports 2010, Brussels.

BirdLife Europe et al. (2010), Changing perspectives: How the EU budget can shape a sustainable future, Brussels.

CEE Bankwatch Network/FoEE (2007), EU funds for public and environment-friendly transport, Brussels.

CEE Bankwatch Network (2009), Explanatory comments on the Polish incinerator project awarded with the RegioScars Award 2009, Brussels.

CoR (Committee of the Regions) (2010), Opinion of the Committee of the Regions on 'Cohesion policy: Strategic Report 2010 on the implementation of the programmes 2007-2013' (2011/C 42/09), Luxembourg.

EEA (European Environment Agency) (2006), Energy and environment in the European Union: Tracking progress towards integration, EEA Report No 8/2006, Copenhagen.

EEA (2010), Towards a resource-efficient transport system: TERM 2009: Indicators tracking transport and environment in the European Union, EEA Report No 2/2010, Copenhagen.

EC (European Commission) (2004), Third progress report on economic and social cohesion, $\operatorname{COM}(2004) 107$ final, Brussels.

EC (2006a), Council regulation (EC) No 1083/2006 of 11 July 2006, Brussels.

EC (2006b), Council decision of 6 October 2006 on Community strategic guidelines on cohesion (2006/702/EC), Brussels.

EC (2007a), Cohesion Policy 2007-13: National Strategic Reference Frameworks, Luxembourg.

EC (2007b), Member States and Regions delivering the Lisbon strategy for growth and jobs through EU Cohesion Policy, 2007-2013, COM(2007) 798 final, Brussels.

EC (2007c), Indicative Guidelines on Evaluation Methods During the Programming Period: The New Programming Period 2007-2013, Working Document No 5, Brussels, DG Regional Policy.

EC (2009), Cohesion Policy backs 'green economy' for growth and long-term jobs in Europe, press release IP/09/369, Brussels.

EC (2010a), Conclusions of the fifth report on economic, social and territorial cohesion: The future of cohesion policy, $\operatorname{COM}(2010) 642$ final, Brussels.

EC (2010b), Cohesion policy: Strategic report 2010 on the implementation of the programmes 20072013, SEC(2010) 360 final, Brussels. 
EC (2010c), Commission staff working document on Cohesion Policy, SEC(2010) 360 final, Brussels.

EC (2010d), Europe 2020: A strategy for smart, sustainable and inclusive growth, $\operatorname{COM}(2010) 2020$ final, Brussels.

EC (2011), Roadmap to a resource efficient Europe, COM(2011) 571 final, Brussels.

Eurostat (2009), Sustainable development in the European Union - 2009 monitoring report of the EU sustainable development strategy, Luxembourg.

FoEE (Friends of the Earth Europe) (2009), Gone to waste: The valuable resources that European countries bury and burn, Brussels.

FoEE (2010), Green scissors: More than $\$ 200$ billion in cuts to wasteful and environmentally harmful spending, Brussels.

GRDP (Greening Regional Development Programmes Network) (2006), Handbook on SEA for Cohesion Policy 2007-2013, Exeter, UK.

Mey, F. (2010), Country case studies: Cohesion Policy Funding - environmental harmful subsidies - a real threat to biodiversity, Presentation 11 January 2010, Brussels.

Nordregio (Nordic Centre for Spatial Development) (2009), The potential for regional Policy Instruments, 2007-2013, to contribute to the Lisbon and Gothenburg objectives for growth, jobs and sustainable development. Final Report to the European Commission, Directorate-General for Regional Policy, Evaluation Unit, Contract No 2007.CE.16.0.AT.041, Stockholm.

OECD (Organisation for Economic Co-operation and Development) (1998), Improving the Environment through Reducing Subsidies, Paris: OECD.

OECD (2005), Environmentally Harmful Subsidies: Challenges for Reform, Paris: OECD.

Schepelmann, P., Stock, M., Koska, T., Schüle, R. and Reutter, O. (2009), A green new deal for Europe: Towards green modernisation in the face of crisis, Wuppertal, Wuppertal Institute for Climate, Environment and Energy.

Schepelmann, P. (2010), A systems theoretical perspective on greening EU regional policy, in Goria, A. (ed.), Governance for the Environment: a Comparative Analysis of Environmental Policy Integration, Cheltenham, UK and Northampton, MA, USA: Edward Elgar, pp. 121-156.

Schwab, O. (2010), Expert Evaluation Network delivering policy analysis on the performance of cohesion policy 2007-2013, task 2: Country report on achievements of cohesion policy, Germany, a report to the European Commission Directorate-General Regional Policy, Brussels.

Simon, J.-M. (2010), When the EU wastes the climate: The EU policy of subsidising energy from burning waste is worsening the climate, Brussels: Global Anti-Incinerator Alliance.

Stefanova, A. and Konecny, M. (2008), EU Structural and Cohesion Funds and their impact on climate, Brussels: CEE Bankwatch/FoEE.

Valsecchi, C., ten Brink, P., Bassi, S., Withana, S., Lewis, M., Best, A., Oosterhuis, F., Dias Soares, C., Rogers-Ganter, H. and Kaphengst ,T. (2009), Environmentally Harmful Subsidies: Identification and Assessment, London and Brussels: IEEP.

Well, L. van (2009), The potential for regional Policy Instruments, 2007-2013, to contribute to the Lisbon and Gothenburg objectives for growth, jobs and sustainable development. Presentation of Final Report Results for DG REGIO Evaluation Network, 3 April, Brussels.

WWF (World Wildlife Fund) (2006), Conflicting EU funds: Pitting conservation against unsustainable development, WWF Global Species Programme, Vienna.

Note: Many items of the evaluation literature above are archived at: http://ec.europa.eu/regional_policy/information/evaluations/index_en.cfm 